\title{
The Laptev Sea flaw polynya, Russian Arctic: effects on the mesoscale hydrography
}

\author{
I. Dmitrenko, ${ }^{1}$ J. A. Hölemann, ${ }^{2 *}$ K. Tyshko, ${ }^{1}$ V. Ghurun, ${ }^{1}$ S. Kirillov, ${ }^{1}$ H. Kassens ${ }^{3}$ \\ ${ }^{1}$ Arctic and Antarctic Research Institute, 199397 St Petersburg, Russia \\ ${ }^{2}$ Alfred Wegener Institute for Polar and Marine Research, P.O. Box 120161, D-27515 Bremerhaven, Germany \\ ${ }^{3}$ GEOMAR Forschungszentrum, Wischhofstrasse 1-3, D-24148 Kiel, Germany
}

\begin{abstract}
A detailed analysis of hydrographic data from a period of 20 years (198099) has shown that the persistent presence of a flaw polynya influences mesoscale hydrography of the Laptev Sea, Russian Arctic. Based on these data, the interannual variability of surface water salinity within the polynya has been estimated. As the salinity increase in the surface water layer is mainly caused by the formation of new ice within the polynya, the average ice-production rate of the polynya was calculated. The results indicate an ice production of 3-4 $\mathrm{m}$ per season. A further aim of this study was to calculate the probability that the convective mixing in the polynya penetrates to the sea-floor. It is demonstrated that the probability is maximal in the flaw-polynya area, but does not exceed $20 \%$ in the eastern and $70 \%$ in the western part of the polynya, as a result of strong vertical density stratification from river runoff, especially in the eastern Laptev Sea. Additional studies of water circulation in the marginal zone of the flaw polynya were carried out during field observations in April-May 1999. On the basis of conductivity-temperature-depth and current measurements we deduce that high current velocities $\left(62 \mathrm{~cm} \mathrm{~s}^{-1}\right)$ recorded in surface waters near the fast-ice edge are caused by a convectively driven circulation system under the polynya. Our measurements indicate that these high-velocity currents are part of a cellular circulation, which results from the rejection of brine during intensive ice formation in the polynya. The observed azimuthal alignment of the crystalline structure of sea ice is also, most probably, the consequence of this quasi-stationary cellular circulation.
\end{abstract}

\section{INTRODUCTION}

The flaw polynyas on the Russian Arctic shelf are an important component of the climatic system. They are created by southerly winds blowing continuously during winter, and can keep open large water areas (up to $100 \mathrm{~km}$ wide) off the fast-ice edge (Zakharov, 1997). Combined with low temperatures, this results in sea-ice formation, brine rejection and local increase in the salinity of the water column in the flaw polynya. The flaw polynya in the Laptev Sea is one of the main sources for ice in the Transpolar Drift (Eicken and others, 1997; Dethleff and others, 1998) and a possible source area for saline shelf waters (Cavalieri and Martin, 1994; Winsor and Björk, 2000).

However, few publications exist concerning the oceanography of flaw polynyas on the Russian Arctic shelf, and none on the influence of polynyas on the mesoscale hydrography of the Laptev Sea in winter. This work examines historical data and analyzes recently obtained field observations in order to evaluate the impact of the Laptev Sea flaw polynya upon the mesoscale hydrography.

\section{ANALYSIS OF HISTORICAL DATA}

The historical hydrographical data (March-May from 1980

* Present address: GEOMAR Forschungszentrum, Wischhofstrasse 1-3, D-24148 Kiel, Germany. until 1999; 1685 hydrographic stations) have shown that in the southern and southeastern regions of the Laptev Sea the area with highest variance in surface water salinity $\left(\Delta_{\mathrm{s}}^{2}\right)$ coincides with the average multi-annual position of the fastice edge and the flaw polynya (Fig. la). We assume that the coincidence of enhanced surface salinity variance with the multi-annual position of the fast-ice edge is an effect of the local salinity increase of the surface water caused by the rejection of salt during ice formation in the quasi-stationary flaw polynya. River runoff is considerably reduced during winter, and only affects the eastern Laptev Sea up to $74^{\circ} \mathrm{N}$. Thus, interannual variability of the winter runoff cannot create the local zone with high salinity variance. Interannual variability of the advection regime is also highly improbable. During winter, ice cover protects the sea from wind stress. Large-scale distribution of the surface sea-water density governing the surface circulation does not change greatly from year to year. Therefore we consider the double surface salinity rms deviation $2 \Delta_{\mathrm{S}}$ as the value of the average salinization due to ice formation in the flaw polynya. The value in the eastern part of the Laptev Sea, $2 \Delta_{\mathrm{s}}=3.5-4.2 \mathrm{psu}$ (practical salinity units), exceeds the estimate of $2-2.5$ psu given by Zakharov (1966), but is close to the observations described below. Estimations of 5.95-6.34 psu (Winsor and Björk, 2000) exceed our values, probably due to a different approach. We did not consider advection of salt waters from the polynya and, hence, obtained a lower estimate of the possible salinity increase.

Salinization by $3.5-4.2 \mathrm{psu}$ is the result of the integral influence of ice formation on water hydrography. Thus it is 


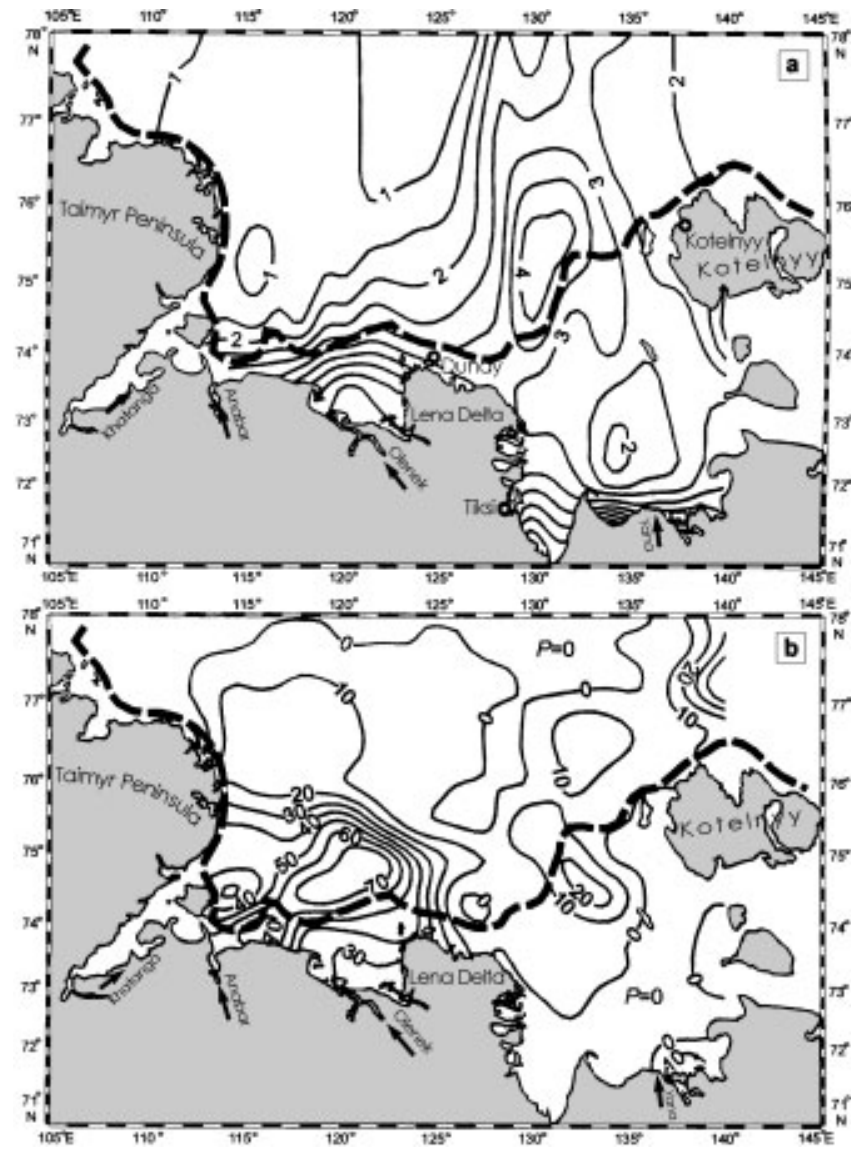

Fig. 1. (a) Variance (psu $\left.{ }^{2}\right)$ of the multi-annual surface salinity distribution in the Laptev Sea, and ( $b$ ) probability ( $P$ $(\%)$ ) of convective mixing penetration down to the sea-floor in winter. Thick dashed line shows average multi-annual position of the fast-ice edge in mid-February.

possible to calculate ice formation in the polynya based on the salinity-anomaly data in this region. For this purpose we have used the average winter vertical distribution of salinity $S(Z)$ and temperature $T(Z)$ in the area of the flaw polynya in the Laptev Sea, calculated from the oceanographic survey data for the period 1980-99. In order to calculate the average ice-formation value $I=I_{k}\left(S_{0}+2 \Delta_{\mathrm{s}}\right)$ we have used the simplest convection model of Zubov (1963):

$$
\begin{aligned}
I_{k} & =\sum_{i=1}^{k} \frac{1.1 H_{i-1}\left(S_{i}-S_{i-1}\right)}{S_{i-1}}, \\
S_{k} & =f\left(\rho_{k}, T\right) ; \quad S_{k}=S_{0}+2 \Delta_{\mathrm{s}},
\end{aligned}
$$

where $i$ is the number of the level in the average multiannual profile in order from the sea surface; $H_{i}$ and $S_{i}$ are the depth and salinity, respectively, at the level $i ; k$ is the level number of the mixing penetration; $H_{k}$ and $S_{k}$ are the depth and salinity, respectively, of the mixing layer; $I_{k}$ is the ice thickness formed when mixing penetrates down to the level $k ; T$ is temperature; $S_{0}$ is average multi-annual surface salinity; and function $f$ is the equation of the sea-water state solved numerically for salinity.

Evaluation of these data shows that the average ice production in the eastern part of the Laptev Sea to mid-April is about 3-4 $\mathrm{m}$ depending on the geographical position of the calculation points. In general, this calculated value corresponds to already published estimates (based on ice observations) of an average ice formation of $3.6 \mathrm{~m}$ in the polynya
(Zakharov, 1966). The value of $14.2 \mathrm{~m}$ by Winsor and Björk (2000) appears to be too high. If such amounts of ice were formed, convective mixing would penetrate down to the sea-floor, which in reality does not occur (Fig. 1b).

To investigate the probability $(P)$ of convective mixing penetration down to the sea-floor we have used the average multi-annual winter surface and bottom water salinity of the Laptev Sea and its rms deviations calculated for the period 1980-99. To calculate $P$ we assumed the distribution of the probability density for the annual values of surface and bottom salinity in winter to be normal. $P$ was determined as the probability of equilibrium between the surface and bottom salinity:

$$
\begin{aligned}
& P=\int_{S_{0}}^{S_{\max }} P_{\text {surface }} \mathrm{d} S_{\text {surface }}+\int_{S_{\min }}^{S_{0}} P_{\text {bottom }} \mathrm{d} S_{\text {bottom }} \\
& P_{\text {surface }}\left(S_{0}\right)=P_{\text {bottom }}\left(S_{0}\right) .
\end{aligned}
$$

The calculated probability $P$ (Fig. 1 b) reflects the vertical density stratification of the water column, which is a consequence of the fresh-water input into the eastern part of the sea. Surface salinity increases offshore from 12-14 psu near the Lena river delta to $28-30$ psu in the northeastern part of the sea. In the polynya region the average multi-annual salinity ranges from 24-27 psu at the sea surface to $27-30$ psu at the bottom. In most of the above-mentioned areas the $P$ values are $0-10 \%$. Only in the region of the flaw polynya are we dealing with a zone of higher $P$ s reaching $20 \%$. In the western Laptev Sea the salinity varies slightly from 30 to 32 psu at the surface and from 30 to 33.5 psu at the bottom. Because of the weak vertical density stratification, probability values here reach $70 \%$. As in the eastern part, the zone of maximal $P$ values coincides with the flaw-polynya region.

The zones of increased $P$ values coincide with the average multi-annual position of the flaw polynyas because of the partial destruction of the density stratification due to salinization accompanying intensive ice formation in the polynya. The highest probability of convective mixing down to the sea-floor was found in the southwestern part of the Laptev Sea, where the influence of Khatanga and Anabar rivers is insignificant. Kara Sea water freshened by the $\mathrm{Ob}$ and Yenisey river runoff also does not reach this area. In the southeastern regions, salinization of the surface layer in the flaw polynyas is not of crucial importance since summer river runoff keeps surface salinity low even in winter.

\section{ANALYSIS OF THE EXPEDITION DATA OF 1999}

Oceanographic investigations were carried out in the eastern Laptev Sea flaw polynya in April-May 1999 during the helicopter expedition TRANSDRIFT VI as part of the joint Russian-German project "Laptev Sea System 2000" (Fig. 2a). During winter 1998/99, the flaw polynya in the Laptev Sea was underdeveloped until mid-March 1999 and was represented by a chain of separate, narrow flaw leads. From the beginning of April, the polynya in the eastern part of the sea began to widen in a northerly direction. By 25 April, the width of the polynya in some places reached $50-60 \mathrm{~km}$. The location and size of the flaw polynya in this part of the sea then remained practically unchanged until the end of the expedition (8 May 1999).

To study the hydrographic processes in the flaw polynya, oceanographic measurements were carried out close to the 

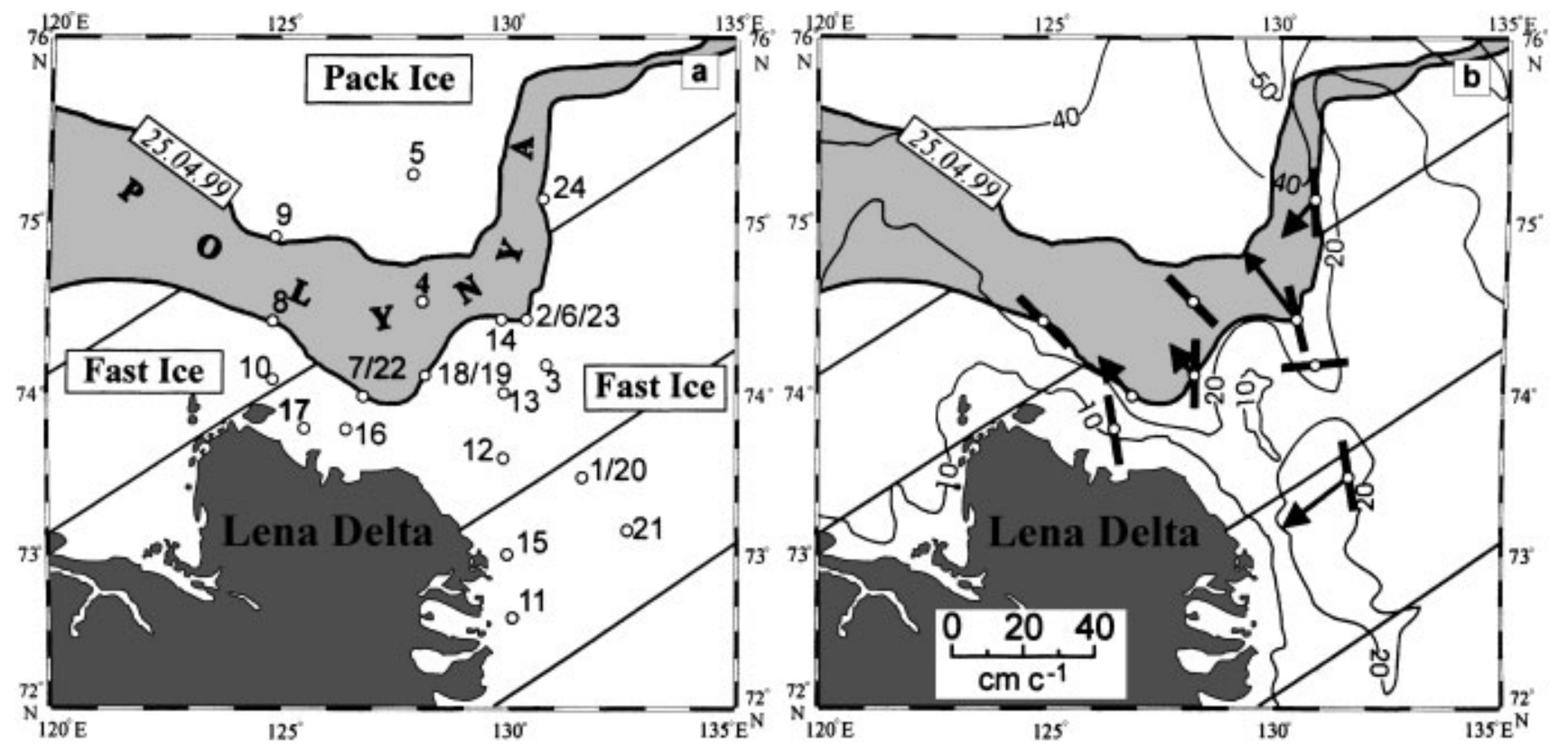

Fig. 2. (a) Station locations and (b) surface currents, and orientation of crystalline sea-ice structure, in April-May 1999 ( TRANSDRIFT VI expedition). ○, oceanographic stations (TI99...); \, vectors of surface currents; $\mathbf{\infty}$, orientation of the crystalline sea-ice structure.

fast-ice edge at stations TI9908, 07/22, 18/19, 14, 02/06/23 and 24 (Fig. 2a). At the main stations TI9902/23, TI9907 and TI9908, measurements were conducted on short transects (500-600 $\mathrm{m}$ long, oriented at right angles to the fast-ice edge). Observational sites were located on the fast ice, at its edge, in the open water and/or on the thin young ice. Conductivity-temperature-depth (CTD) measurements from the fast ice were carried out with an online CTD (ME OTS-3), and in open waters and from thin ice with an internally recording CTD (Seabird). A three-dimensional acoustic current meter (3D-ACM from FSI) was used for the current measurements. All current observations were carried out from stationary ice.

At stations TI9901, 2, 3, 4, 7, 8, 9, 11, 16, 17, 18 and 24, ice coring was carried out to analyze the crystalline structure of sea ice. The type of crystalline ice structure was determined with a plane-polarized arrangement, which revealed the spatial orientation of crystals, and the orientation of the basic plates and the $c$ axes in the horizontal plane. Subsequent analysis of $<1 \mathrm{~mm}$ thick slices (horizontal dimensions $9 \mathrm{~cm} \times 12 \mathrm{~cm}$ ) allowed approximate determination of the level corresponding to the onset of spatial crystal alignment.

The observed value of the salinity increase, related to the intensive ice formation in the polynya, varied from 1 psu (stations TI9902, 8) to 5 psu (station TI9923, Fig. 3). At stations situated close to (100 $\mathrm{m}$ to $5 \mathrm{~km}$ from) the fastice edge, we recorded under-ice currents in the surface water layer down to the pycnocline that were directed towards the open water (stations TI9918, 24 (Fig. 2b); 23a (Fig. 3)). In the underlying layer, the currents were in the opposite direction (except for station TI9918). Their velocities were 10-24 cm $\mathrm{s}^{-1}$. Directly at the edge of the fast ice (station TI9923) the current velocity of the under-ice layer was $62 \mathrm{~cm} \mathrm{~s}^{-1}$ with a direction of $26^{\circ}$ (northeast). In the layer below the pycnocline, the nearly opposite $\left(230^{\circ}\right)$ current at $4.6 \mathrm{~m}$ depth had a velocity of $26 \mathrm{~cm} \mathrm{~s}^{-1}$ (Fig. 3). Here the direction of $26^{\circ}$ is perpendicular to the local fast-ice edge. Observations at station TI9923 were carried out in calm weather. The velocity of the northeasterly wind did not exceed $5 \mathrm{~m} \mathrm{~s}^{-1}$. A similar phenomenon was observed at the ice-edge stationTI9922: at $3.8 \mathrm{~m}$ depth, a current with a velocity of $5.9 \mathrm{~cm} \mathrm{~s}^{-1}$ was directed northeastward $\left(320^{\circ}\right)$ towards the open water. In the pycnocline, at $8.5 \mathrm{~m}$ depth, a current with a velocity of $5.8 \mathrm{~cm} \mathrm{~s}^{-1}$ and approximately in the opposite direction $\left(115^{\circ}\right)$ was registered. Under the thin ice which had formed in the marginal area of the flaw polynya, the under-ice currents were opposite in direction to the currents below the fast-ice cover (stationTI9919, 23d). They were homogeneous from the surface down to the sea-floor.

Stable under-ice surface currents directed towards the open water (mainly a flaw lead) have repeatedly been observed in the Arctic during winter (Smith and others, 1990; Morison and others, 1992). Smith (1973) was the first to give a physical interpretation for these currents. He explained them as the result of cellular circulation developing due to salinization of the surface water layer by ice formation. The salt rejection leads to the formation of circulation cells in which the upper under-ice layer moves towards the open water. In the lower part of the upper quasi-homogeneous layer, a compensatory counter-current is generated. The measured velocities of these currents tend to vary between 2 and $12 \mathrm{~cm} \mathrm{~s}^{-1}$. Calculations of circulation in flaw leads based on

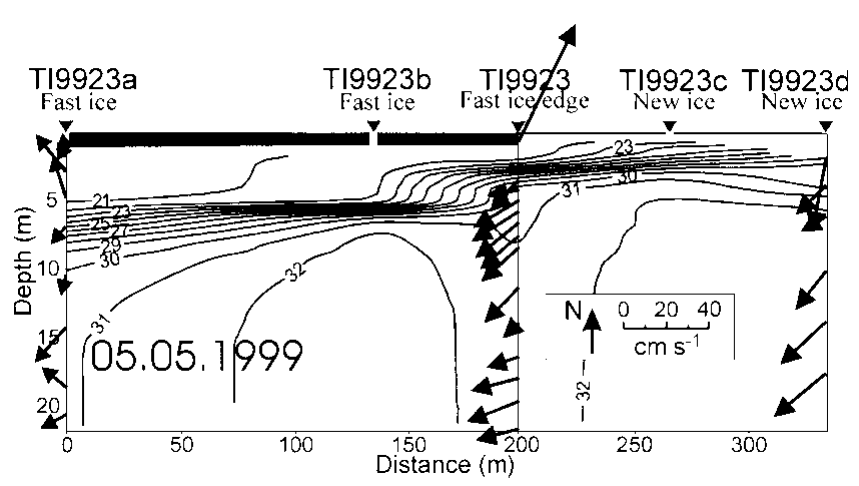

Fig. 3. Salinity (psu) and current distribution on the microtransect across the fast-ice edge, station TI9923. 
Table 1. Calculated dates of the onset of alignment formation in sea-ice crystalline structure

$\begin{array}{cccc}\text { Station No. } & \text { Date } & \text { Ice thickness } & \text { Ice thickness at Approximate date of } \\ \text { (T199...) } & & \text { at time of } & \text { onset of alignment onset of alignment } \\ \text { investigations }(I) & \text { formation }\left(I_{0}\right) & \text { formation }\end{array}$

$\mathrm{m}$

$\mathrm{m}$

\begin{tabular}{rrrcc}
\hline 1 & 17 April 1999 & 2.08 & 1.00 & 16 November 1998 \\
2 & 19 April 1999 & 0.92 & 0.70 & 26 March 1999 \\
3 & 21 April 1999 & 1.68 & 1.35 & 25 February 1999 \\
4 & 23 April 1999 & 1.60 & 0.80 & 13 January 1999 \\
8 & 26 April 1999 & 0.68 & 0.30 & 26 March 1999 \\
16 & 30 April 1999 & 2.08 & 1.70 & 13 February 1999 \\
18 & 01 May 1999 & 1.08 & 0.80 & 24 March 1999 \\
24 & 06 May 1999 & 1.39 & 0.90 & 27 February 1999 \\
\hline
\end{tabular}

numerical models (Smith and Morison, 1993) show that for the oceanographic conditions typical for the Beaufort Sea, the current velocity can reach $8 \mathrm{~cm} \mathrm{~s}^{-1}$ in the case of free convection. Horizontal dimensions of the circulation cells may reach $1000 \mathrm{~m}$. The character of the circulation, registered along the short transects in the marginal zone, generally correspond to those calculated by Smith and Morison (1993) for free convection with salinity stratification. As in the numerical simulation, the current in the upper water layer above the pycnocline is directed towards the open water of the polynya. In the underlying layer, the current is in the opposite direction. The zone of convergence is observed below the open water of the polynya (Fig. 3). This would suggest that the surface currents registered in the marginal region are likely related to salinization during ice formation in the flaw polynya. They are directed towards the open water and are an element of the circulation cells with counter-currents in the opposite direction in their lower part, i.e. in the pycnocline.

Alignment of the crystalline structure in the ice cover of the marginal zone also indicates the quasi-stationary character of the under-ice currents directed towards the flaw polynya. Stable under-ice currents tend to cause spatial azimuthal alignment of sea-ice crystals (Stander and Michel, 1989). Data confirm that dependence under natural conditions correlates well with the results of laboratory experiments (Cherepanov and Strakhov, 1989). Investigation of the ice structure showed an azimuthal spatial crystal alignment in the lower layers at stations TI9901, 2, 3, 4, 8, 16, 18 and 23 (Fig. 2b). At stations TI9901, 2, 4, 8, 16 and 18, the $c$ axis of crystals was generally oriented southeast-northwest, and at station TI9924 south-north. A layer-by-layer analysis of the horizontal ice structure made it possible to determine the horizon below which the spatial crystal-alignment formation was initiated. Taking into account daily air temperature from Tiksi, Dunay and Kotelnyy meteorological stations (Fig. la), we estimated the starting time of alignment (Table 1) based on Zubov (1963). The spatial alignment of crystalline ice structure at the marginal stations TI9902, 8 and 18 occurred after 24-26 March, which is exactly when the flaw polynya started to grow. On the RADARSAT ScanSAR satellite image dated 21 March, the flaw polynya is absent. A strong southeasterly wind $\left(90-110^{\circ}\right)$ with speeds of $10-16 \mathrm{~m} \mathrm{~s}^{-1}$ that blew from 24 to 29 March (data from the Kotelnyy meteorological station) led to the development of the flaw polynya, which is well depicted on the satellite image of the eastern Laptev Sea from 5 April. Therefore it appears that the alignment of the crystal- line ice structure in this case was created by a stable system of under-ice surface currents directed towards the open water in the flaw polynya.

\section{CONGLUSIONS}

It has been shown that the polynya plays a leading role in mesoscale hydrography of the Laptev Sea during winter. In the eastern Laptev Sea flaw-polynya area the mean salinity increase of the surface layer can reach 3.5-4.2 psu, corresponding to a mean ice production in the polynya of 3-4 $\mathrm{m}$. Because of the strong density stratification, haline convection in the polynya area cannot reach the sea-floor in more than $20 \%$ of the cases. In the southwest, where the river influence is considerably smaller, the probability increases to $70 \%$.

Brine rejection during ice formation in the polynya leads to the formation of a cellular circulation. The under-ice surface layer moves with a velocity reaching $62 \mathrm{~cm} \mathrm{~s}^{-1}$ towards the open water of the flaw polynya. The underlying layer moves in the opposite direction. The circulation is probably quasi-stationary. This is the main reason for the formation of the crystalline structure alignment of the sea ice in the marginal zone of the flaw polynya.

\section{ACKNOWLEDGEMENTS}

The authors are grateful for the financial support of the Russian Ministry for Science and Technology and the German Ministry for Education and Research within the framework of the Russian-German project "Laptev Sea System 2000". Two anonymous reviewers provided helpful comments and criticism.

\section{REFERENGES}

Cavalieri, D. J. and S. Martin. 1994. The contribution of Alaskan, Siberian, and Canadian coastal polynyas to the cold halocline layer of the Arctic Ocean. F. Geophys. Res., 99 (C9), 18,343-18,362.

Cherepanov, N.V. and M.V. Strakhov. 1989. Laboratornie issledovaniya orientirovannogo rosta kristalov l'da $\mathrm{v}$ dvijushemsya vodnom potoke [Laboratory studies of oriented growth of ice crystals in a moving stream of water]. In Bogorodskiy, V.V. and V. P. Gavrilo, eds. [The electrophysical and physicomechanical properties of ice]. Leningrad, Gidrometeoizdat, 134-145.

Dethleff, D., P. Loewe and E. Kline. 1998. Detailed investigation on ice formation and export during 1991/1992 winter season. Cold Reg. Sci. Technol., 27 (3), 225-243.

Eicken, H., E. Reimnitz, V. Alexandrov, T. Martin, H. Kassens and T. Viehoff. 1997. Sea-ice processes in the Laptev Sea and their importance for sediment export. Continental Shelf Res., 17(2), 205-233.

Morison, J. H., M. G. McPhee, T. B. Curtin and C. A. Paulson. 1992. The oceanography of winter leads. F. Geophys. Res., 97(C7), 11,199-11,218.

Smith, D. C., IV, and J. H. Morison. 1993. A numerical study of haline convection beneath leads in sea ice. 7. Geophys. Res., 98(C6), 10,069-10,083.

Smith, J. D. 1973. Lead driven convection in the Arctic Ocean. EOS, 54, $1108-1109$.

Smith, S. D., R. D. Muench and C. H. Pease. 1990. Polynyas and leads: an overview of physical processes and environment. f. Geophys. Res., 95(C6), 9461-9479.

Stander, E. and B. Michel. 1989. The development of aligned columnar sea ice: a field investigation. F. Glaciol., 35(120), 217-223.

Winsor, P. and G. Björk. 2000. Polynya activity in the Arctic Ocean from 1958 to 1997. F. Geophys. Res., 195(C4), 8789-8803.

Zakharov, V. F. 1966. Rol' zapripaynih poliney v gidrologicheskom i ledovom rejime morya Laptevih [The role of trans-fast ice polynyas in hydrological and ice regime of the Laptev Sea]. Okeanologiia, 6(6), 1014-1022.

Zakharov, V. F. 1997. Sea ice in the climate system. Geneva, World Meteorological Organization. World Climate Research Programme. Arctic Climate System Study. (WMO/TD 782.)

Zubov, N. N. 1963. Arctic ice. San Diego, CA, U.S. Navy Electronics Laboratory. (Translation of L'dy Arktiki, Izdatel'stvo Glavsevmorputi, Moscow.) 